\title{
Proposed Restructuring Strategy For Sustainable Future Of Pt Pos Indonesia
}

\author{
Ignasia Tiffani and Harimukti Wandebori
}

\begin{abstract}
PT Pos Indonesia (Persero) as one of the oldest SOEs in Indonesia strives to survive in the 4.0 industry era. One of the efforts is by diversifying its business. However, the current strategy implemented is not in accordance with the current condition of the company. It can be seen from the performance of PT Pos Indonesia which has been getting worse from year to year and does not reach the planned company targets. The condition causes a value-reducing for PT Pos Indonesia. To identify problems in this research using external analysis, internal analysis, and SWOT analysis. This research uses qualitative methods using primary data and secondary data. The business issue of PT Pos Indonesia is the performance and sustainability of PT Pos Indonesia which is getting worse related to business units and affiliations. To find the appropriate solution for company's problem, this research proposes a new corporate strategy by restructuring. The tool used in analyzing corporate restructuring in this research is hexagonal restructuring. Hexagonal restructuring can help company to examine constraining opportunities to valuecreating by improving operations, restructuring its business, managing assets, and improving governance. The research focused on determining corporate strategies that can be proposed to be implemented. The research was expected to provide contributions for the research on hexagonal restructuring theory.
\end{abstract}

Index Terms - Postal Industry, Corporate Strategy, Restructuring, Hexagonal Restructuring.

\section{INTRODUCTION}

According to data from Badan Pusat Statistik (BPS) Indonesia, the transportation and warehousing Industry on contributing to Gross Domestic Product (GDP) in Indonesia is in the 10th largest, which ranks 6. And accounted for $5.37 \%$ of Indonesia's GDP in 2018 (BPS, 2019). The movement of the transportation and warehousing sector over the past five years is supported by the performance of the subsector in the sector, particularly from the subsector of warehousing, supporting services for transportation, postal, and courier services. This subsector has the third largest contribution to the transportation and warehousing sector with an average of $16.4 \%$ [16]. In the industrial era 4.0, technological developments create innovations which can increase time efficiency.

This condition opens up opportunities for postal and shipping service companies in Indonesia, one of them is PT Pos Indonesia as a State-Owned Enterprise. Not only is PT

Published on July 4, 2020.

Ignasia Tiffani, Bandung Institute of Technology, Indonesia.

(corresponding e-mail: ignasia.tiffani@sbm-itb.ac.id)

Harimukti Wandebori, Bandung Institute of Technology, Indonesia.

(e-mail: harimukti@sbm-itb.ac.id)
Pos Indonesia a player in this field, there are also other competitors from private companies that see this business opportunity, this makes conditions that were previously blue-ocean turned into red-ocean and competition in the industry is tight and forces companies to give their best. Therefore, to answer the challenges and competition in this era, PT Pos Indonesia took strategic action by forming a subsidiary, revitalizing the core business and diversification the business to increase profits. However, the current strategy implemented by PT Indonesia is not in accordance with the current conditions. The revenue has increased, but the net profit has decreased. This can be seen from the performance that has got worse from year to year and the performance does not reach the planned target [18].

The subsector of warehousing, transportation support services, postal services and courier services is quite a large contributor to GDP which provide the implied element that the industry still provides optimistic opportunities for companies engaged in it. But seeing the increasingly unclear circumstances of the direction of PT Pos Indonesia in surviving in competition and sustainability. The purposed of research focused on determining corporate strategies that can be proposed to be implemented for solution to the problems of PT Pos Indonesia, that is the performance and sustainability of company which is getting worse related to business units and affiliations.

This study provides Hexagonal Restructuring that requires company to create value by find the perception gap, improve their operations, disposal, find new growth opportunity, engineering their financial and take the maximum opportunity. The result gives contributions for the Hexagonal Restructuring theory especially in restructuring strategy. The theoretical foundation related to Hexagonal Restructuring used in this research is from Wandebori's Manajemen Strategi Dalam Perspektif Indonesia book, Koller's Valuation: Measuring and Managing the Value of Companies book, and McKinsey on Finance: Perspectives on Corporate Finance and Strategy journal. Each step on the hexagonal restructuring framework, moving from current market value to total potential value [3]. Hexagonal Restructuring can also help in identifying gaps in perceptions between investors and management about the prospects of the business [1]. Hexagonal Restructuring assists managers in diagnosing the vulnerability of the company, identifying value waiting to be captured, and planning a path forward [7].

\section{LITERATURE REVIEW}

\section{A. External Factor Analysis}

External analysis aims to determine the opportunities and threats in the macro environment, industrial and competitive 
that occur in a company. PT Pos Indonesia's external analysis was carried out using a general environment, industry, and competitor approach.

For the general environment, its use PESTEL analysis to understand variables on a macro scale that can affect PT Pos Indonesia in the formulation of a strategy both directly and indirectly. There are seven segments analyzed, which is political, economic, social, technological, environmental and legal. In Indonesia has policies regulations governing the post, regulates the implementation of Universal Post Services/Public Service Obligation and some other regulations which impact the company. Indonesia's economic growth in 2018 was $5.17 \%$, it is an increase compared to 2017 which was $5.07 \%$ (BPS, 2019). The GDP subsector of warehousing, supporting services for transportation, postal, and courier services had the third largest contribution to the transportation and warehousing sector with an average of $16.4 \%$ [16]. In the digitalization era, the lifestyle of society has changed, now all are internet based. E-commerce in Indonesia during the last 10 years has grown by around $17 \%$, with the number of businesses reaching 26.2 million units [19]. In this 4.0 industry era, various industrial sectors are carrying out digital transformation, which aims to improve the quality of services that are effective, efficient, transparent and accountable. For the postal, courier, and logistics industry, factors such as climate and weather greatly affect business operations, because in this industry use a transportation system to operate the business either by land, sea and air [14].

To analyze the industry using Porter's Five Forces, which aims to see how attractive an industry is related to revenue, profitability, and intensity of competitors and consists of threat of new entrants, bargaining power of suppliers, bargaining power of buyers, threat of substitutes, and rivalry among existing firms [6]. The summary of Porter's Five Forces analysis of postal and courier service industry are as follows:

- Threat of new entrants: High

Low barrier to entry in this industry because the technology of postal and courier service is easily imitated, many investors are interest in the postal and courier service industry [12], low customer loyalty in this industry, and has antitrust laws in this industry.

- $\quad$ Bargaining power of suppliers: High

Suppliers in this industry can easily carry out forward integration, because there are quite a lot of newcomers in this industry, therefore suppliers have the opportunity to get orders from these newcomers [12]. Suppliers in this industry are transportation providers, such as aircraft and ship, without support from aircraft, land transportation and ship companies, shipments will be hampered [13]. There are only a few suppliers in this industry while there are many buyers [9].

\section{- $\quad$ Bargaining power of buyers: High}

Low switching cost in this industry, low customer loyalty in this industry, lots of companies engaged in this industry because there are quite a lot of newcomers, so buyers have many options of the courier service companies to consume this service [12], and the online market place has carried out backward integration.

\section{- $\quad$ The threat of substitutes: Medium}

In terms of mails, the postal industry already is replaced by emails and social media [14]. But in its function as a package delivery service until now the threat to substitutes is still low, there are no other substitute products or services available [9]. The disruptive technology to replace courier service still not high[12].

\section{- $\quad$ Rivalry among existing firms: High}

High barrier to exit in this industry, lots of competitor either old competitor or new competitor in this industry, and high attractiveness of this market because companies in this industry compete with each other through various promotions and prices to attract customers [12].

And for the analysis of competitors aims to understand how aggressive competitors are doing in implement their strategy. It is using four components that are objective, assumption, strategy, and capability. The biggest competitor of PT Pos Indonesia on the courier service industry in Indonesia is JNE, J\&T, Tiki, and DHL. PT Pos Indonesia is ranked 4th with a total index of 5.4\% (Top Brand Award, 2019). For the Asian continent, Japan is in the top grades, Japan Post Co., Ltd. as national postal services ranked 4th in the world in 2019 and Indonesia is ranked 59th out of 172 [17].

\section{B. Internal Factor Analysis}

Internal analysis conducted includes resources and value chain activity as the basis for capabilities and core competencies in achieving competitive advantage [2]. PT Pos Indonesia's internal analysis using the Resources Analysis and Value Chain Activity approach. Internal analysis aims to determine the strengths and weaknesses of a company.

For resources analysis, covering tangible and intangible [2]. Tangible discusses the resources that can be seen, heard and touched [1]. The tangible resources of PT Pos Indonesia in terms of financial, organizational, technological, and physical. According to PT Pos Indonesia's financial report within the last three years, PT Pos Indonesia experienced financial problems. The revenue is increase but the income is getting down from year to year and the cash flow of PT Pos Indonesia, the value is negative and from year to year, the negative value gets bigger [18]. The bureaucratic culture at PT Pos Indonesia is still strong, this is a limitation of companies to move quickly with high entrepreneurship demands in order to work on dynamic market developments [11]. PT Pos Indonesia does not quickly change the work process with the business environment, everything goes according to the standard operational procedure [15]. PT Pos Indonesia was late in transforming in terms of technology, consumers left and turned to competitors who were considered capable of answering the latest needs. PT Pos Indonesia has 4,543 post offices, 32,136 other postal facilities, 18,799 other postal services, and 382 mobile postal service units [18]

The intangible are nonphysical entities, which consist of human resources, reputation, innovation ability and brand name [1]. PT Pos Indonesia employees' satisfaction is low, due to the many violations related to employee welfare by PT Pos Indonesia that were not carried out, such as the existence of maladministration and termination of unilateral 
employment. In February 2019, the employee held a demonstration related to salaries that were postponed. PT Pos Indonesia made service innovations, including Contact Center O-Ranger, Magenpos, B2B Courier Post Agents, B2B Postal Services Financial Services, and Air Retail Cargo Services [10]. But the innovation of the O-Ranger program has not been realized to the fullest, the cause is the partnership scheme that has not been able to attract partners. PT Pos Indonesia's experience in this industry has reached approximately 270 years, with this experience, of course, PT Pos Indonesia already knows the ins and outs of this industry. But the stigma of PT Pos Indonesia in the public that sending goods through PT Pos Indonesia takes a long time compared to other shipping services is difficult to remove.

For value chain analysis is used to understand what parts of a company's operations create value and what does not [2]. It is divided into two activities to be analyzed, which is primary activity and support activity. In primary activity, analyzed include inbound logistics, operations, outbound logistics, marketing and sales, and after sales. PT Pos Indonesia's inbound logistics activities include finding customers and getting the package from customers to be sent [14]. This service industry is divided into two types of buyers, which is Business to Business (B2B) and Business to Consumer (B2C). PT Pos Indonesia has not yet penetrated all e-commerce in Indonesia, only a few ecommerce companies have collaborated with PT Pos Indonesia. The operation process, sometimes it takes a long time, causing complaints from customers. The slowness of the operating system becomes an obstacle in this process. During this process sometimes the receipt tracking status is not updated in the tracking application. The delivery of the package can be adjusted to the customer's request, which is delivered to the recipient's address or taken at the destination post office. The marketing of PT Pos Indonesia is less competent in the 4.0 industry era. PT Pos Indonesia is still slow and not aggressively promoting its service products. For customer service through social media and telephone available 24 hours, while complaints through the post office are not all regions open 24 hours.

In support activity, analyzed include firm infrastructure, procurement, human resource management, and technology development. The infrastructure firm of PT Pos Indonesia is not going well because the Good Corporate Governance (GCG) still not fully implemented and still bad. PT Pos Indonesia created an e-Procurement System for vendor registration and made auction announcements regarding equipment and supplies needed. PT Pos Indonesia experienced difficulties in increasing the cost of human resources such as an increase in salary expenses, the presence of new employees, an increase in transportation costs and an increase in outsourcing costs. The technologies currently applied by PT Pos Indonesia have already been applied by its competitors.

\section{SWOT Analysis}

SWOT analysis seeks to find the factors that are strengths and weaknesses that are owned by the company from internal and factors that become opportunities and threats arising from external [5]. The situation of PT Pos Indonesia analyzed through SWOT analysis, from the results of internal and external analysis.

\section{Methodology}

The methodology used qualitative approach, with the primary data method and secondary data method. The primary data in this research was obtained through interviews with the representative of the company. The secondary data were obtained through literature studies. The literature of the study in this research was obtained from annual report, previous journal and research, website and online article.

\section{FINDINGS AND ARGUMENT}

After analyzed the external factor, internal factor, and SWOT of the company, the solution can be proposed for the issue of the problem (Fig. 1). The business that has been carried out by PT Pos Indonesia has diversified, there are businesses that are related to the core business and there are also businesses that are not related to the core business. The level of diversification that has been carried out by PT Pos Indonesia is included in the moderate to a high level related link. The current strategy does not related with the current company position.

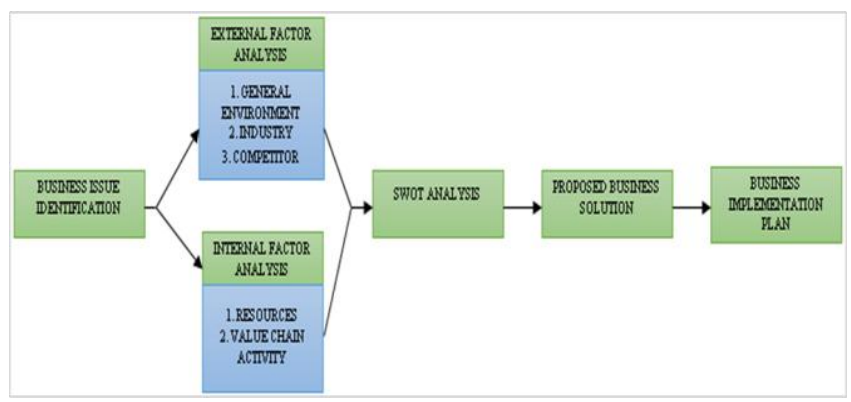

Fig. 1. Research Framework.

\section{A. TOWS Matrix}

The TOWS matrix shows how the opportunity and threat conditions faced by the company can be integrated with the company's internal conditions which include strengths and weaknesses that produce four alternative types of strategies [4]. The TOWS matrix of PT Pos Indonesia that was developed based on the SWOT analysis.

\section{B. Restructuring}

In connection with the current condition of PT Pos Indonesia, turnaround strategy must be carried out through restructuring because the weaknesses that occur can still be overcome and can be corrected to achieved the goal and improve the performance and the sustainability. There are two stages in restructuring, which is contraction and consolidation. Contraction is a strategy to cover sources of loss by selling unproductive assets or unrelated business units. Consolidation is carried out after the contraction is carried out, by searching for new target segments or creating new products and services [1]. 


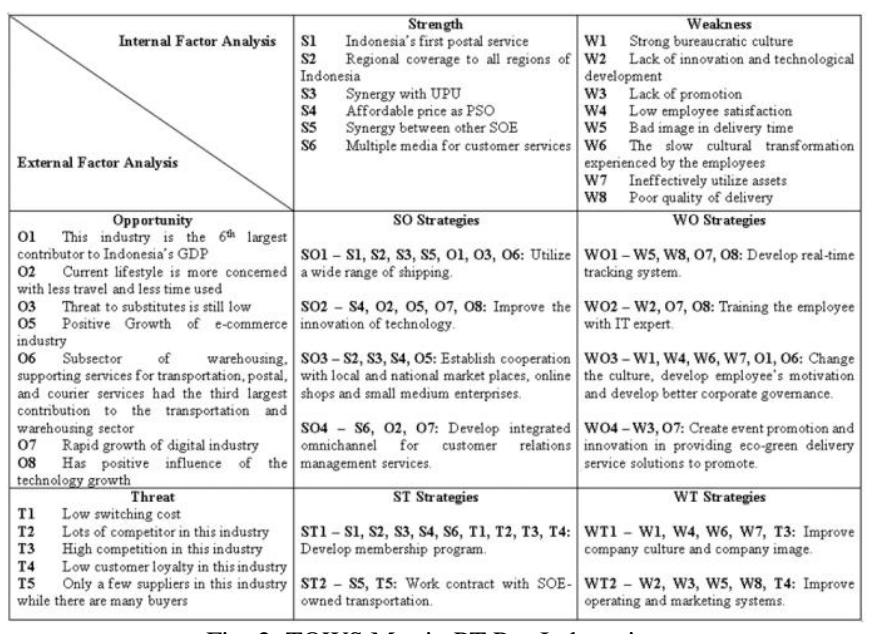

Fig. 2. TOWS Matrix PT Pos Indonesia.

\section{Hexagonal Restructuring}

The strategy formulation to conduct a corporate restructuring analysis of PT Pos Indonesia is develop through the hexagonal restructure framework. Hexagonal restructure framework can help company to examine the limiting opportunities [8]. And management can also take steps to ensure that current market valuations reflect current strategies and performance of the company and improvements over time [7]. So that PT Pos Indonesia can survive in the industry 4.0 era to remain profitable and sustainable.

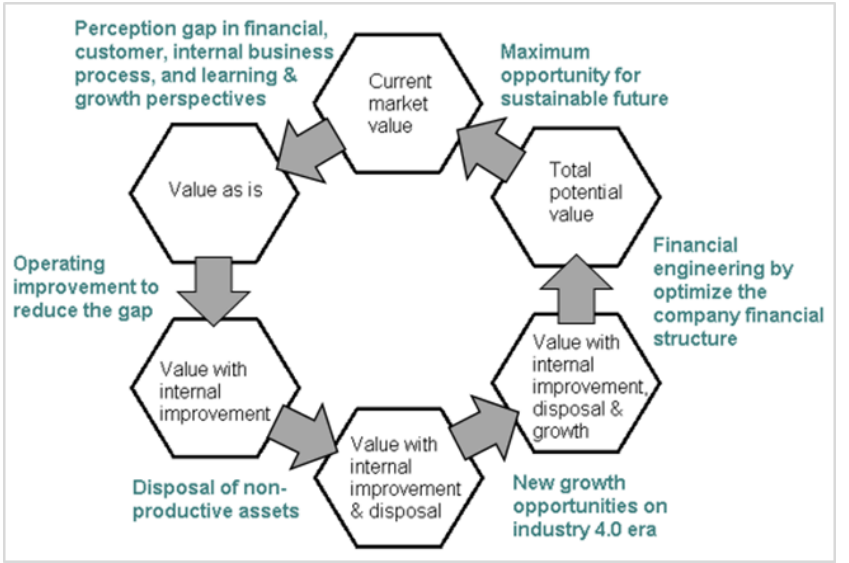

Fig. 3. Hexagonal Restructuring Framework.

Based on Figure 3 there are 6 steps in analyzing PT Pos Indonesia using the hexagonal restructuring framework. Following is the step of hexagonal restructuring:

\section{1) Perception Gap}

The first step is compares the current value of PT Pos Indonesia with the value of PT Pos Indonesia in accordance with achieving the vision so that gaps can be determined. To achieve the vision, it needs benchmarking from the best practices in this industry. The best practice in this final project is based on the Universal Postal Union in Asia is Japan [17]. The gap in the financial is large, the financial performance provided by PT Pos Indonesia is not enough to achieve the expected value. The gap in customer experience shows that PT Pos Indonesia still has to improve its service performance to increase customer satisfaction. The gaps in the internal business processes is large, PT Pos Indonesia must continue to improve the synergy of each work unit in order to produce a good internal business process so that all elements are controlled and well-coordinated so that harmony arises during the business process. The gap in perspective of learning and growth is large, the company's growth and development process will face many obstacles.

\section{2) Operating Improvement}

The second step is to reduce gaps, especially from the perspective of customers, internal business processes, and learning and growth. The activities in a value chain activity are activities that must be improved in the operating improvement to reduce the gap. Following is the operating improvement:

1. Inbound Logistic: Partnerships with B2B market; Flexibility on integrated pickup system; Utilizing the post office network through the deployment of unique post offices according to regional needs.

2. Operations: Barcode system; Computerized \& automation system; Contract with SOE-owned transportation; Utilize a wide range of shipping; Partnership with international; logistics companies.

3. Outbound Logistic: Real time tracking; Maintain the quality of the package.

4. Marketing \& sales: Membership program; Utilized O-Ranger and Post Agent; Event promotion; Eco-green campaign.

5. After Sales: Integrated omnichannel customer service.

6. Firm Infrastructure: Improve inter-department communication; Flat organization; Obey the government rules.

7. Procurement: Create stock card; Maintain the relationship with vendor.

8. Human Resources Management: Bottom-up relationship; Employee training; Fairly salary and allowance system; Employee incubator; Improve professionalism.

9. Technology Development: Information Technology (IT) platforms; Integrating different IT systems between divisions.

\section{3) Disposal of Non-Productive Asset}

The third step is selling unproductive assets. The goal is to get one of the sources of cash needed in the restructuring stage as well as for management to refocus on its core business. PT Pos Indonesia's core business is postal and courier services. The services of PT Pos Indonesia's products are postal, courier service, logistics and financial transactions, which related to the core business. Therefore the others business which unrelated to the core business should be disposed.

PT Pos Indonesia has one subsidiary, two affiliates and four affiliate subsidiaries, which are unrelated business with core business and make it a value-reducing for PT Pos Indonesia, these seven business are low strategic/competitive business units, low operational and cost leveraging, and PT Pos Indonesia as the holding company does not have expertise in this field. Therefore the seven non-productive assets should be disposed. Based on the estimated price, the funds to be obtained by PT Pos Indonesia amounted to IDR 5,036,518,017,202.-. The funds obtained from the sale of assets can be utilized by PT Pos 
Indonesia to support the main business operations, supporting businesses and synergy business so that there is an improvement in the performance.

\section{4) New Growth Opportunity}

Based on an analysis of the general environment, industry and competitors changes in the business environment including customer needs, operational processes, to encourage business innovation focus on automation, artificial intelligence, information technology and the Internet of Things. The post and courier industry has a positive influence on technological growth. The rapid growth of the digital industry can provide opportunities for this industry. By utilizing the technology and innovating in providing sophisticated services at affordable prices because PT Pos Indonesia is UPS as stipulated in Law No. 38 of 2009 and its application is regulated in the Minister of Communication and Information Regulation No. 22 of 2003. PT Pos Indonesia must utilize this opportunity in order to improve its performance including profit and sustainability. Innovations must still be made by PT Pos Indonesia in order to return to be the market leader in this industry, with technological developments, especially the emergence of new technologies. Determine the points of difference and new points of parity that are in accordance with the positioning and value proposition of PT Pos Indonesia's products and services.

The services of PT Pos Indonesia's products are postal, courier service, logistics and financial transactions, which related to the core business. To create new features, PT Pos Indonesia must develop a global hub network and gateway, and barcode system sorting technology that automates postal business, courier service and logistics so that it can run faster in line with the needs of the people in this globalization era where everything must be fast-paced and integrated. For its supporting business in financial transactions, it can collaborate with offline market places and outlets. Some of the funds generated from the sale of unproductive assets can be used to realize these opportunities.

\section{5) Financial Engineering}

The good corporate financial criteria include a debt ratio of less than 1 and positive cash growth. However the PT Pos Indonesia's debt to equity ratio in 2018 is 1.19 times and the cash flow decrease in the amount of IDR 293 billion [18]. There are still many outstanding debts held by PT Pos Indonesia and negative cash growth, these are a risk for PT Pos Indonesia. The financial engineering of PT Pos Indonesia such as debt convert to ownership (debt to equity swap). Other things can be done by PT Pos Indonesia by modifying the terms of debt by reducing the interest rate for the remaining debt period, extending the repayment period, reducing the number of principal and reducing the interest owed. Lease payable and bank loan can modified by extending the repayment period. Because the short term debt is bigger, it can be modified by extending the repayment period. PT Pos Indonesia must negotiate with creditors regarding these debts in accordance with applicable financial accounting standards. The new structure after financial engineering is financial is IDR 200,000,000,000 of debt changes to equity, IDR $3,522,200,042,647$ of debt do extending the repayment period; and IDR 1,084,916,314,062 of debt still same.

\section{6) Maximum Opportunity}

After contraction and consolidation conducted at PT Pos Indonesia to fit the expected vision, the target can be achieved and PT Pos Indonesia's performance can be improved. PT Pos Indonesia must transforming for a sustainable future. By returning to focus on the core business is expected to be value-creating. So that in accordance with the strategy that has been proposed by the Ministry of SOEs, that are the management changes, looking for the right business model but must remain in the core business and look at technological opportunities.

\section{CONCLUSIONS}

The suitable solution to improve the performance both in terms of profit and sustainability that can be implemented by PT Pos Indonesia is to implement the new corporate strategy. The new proposed corporate strategy for PT Pos Indonesia will be implemented by a restructuring strategy. Implementing new strategy was expected to be the solution to the problems of company, because PT Pos Indonesia must transforming for a sustainable future. According to the new corporate strategy, the implementation plan is carried out through hexagonal restructuring. If this strategy is successfully implemented, it is expected that in the following year, PT Pos Indonesia will be able to create value-creating so that it can survive in the industry 4.0 era to remain profitable and sustainable future.

In addition, this research use TOWS matrix to generate the second step of hexagonal restructuring, that is operating improvement. The strategy in the TOWS matrix is used in developing operations improvement in value chain activities. These alternative strategies can be applied in business operations of the company to reduce gaps, especially from the perspective of customers, internal business processes, and learning and growth. This additional step is more effective, structured and measurable in stages in an effort for the company to adjust changes so massive and fast so that the vision can be achieved

\section{A. Research Limitation}

The limitation of the research, first is the latest annual report of company has not released at the time the final project was being worked on. Second is because PT Pos Indonesia is classified as State-Owned Enterprises and eager to develop, therefore the data and the information gathered were limited.

\section{B. Further Research}

For further research can add other tools and can expand literature study in evaluating and formulating strategies to deepen the results of the analysis. In this research has determined what assets should be disposed, engineering the financial aspect, what should be developed by PT Pos Indonesia, further research can analyze the existing business unit valuation to generate the value of asset and generate the valuation for the parent company after restructuring, to know future cash flow of the company. 


\section{REFERENCES}

[1] Wandebori, H., 2019, Manajemen Strategi Dalam Perspektif Indonesia, Bandung: ITB Press.

[2] Hitt, M. A., Ireland, R. D., \& Hoskisson, R. E., 2007, Strategic Management: Competitiveness and Globalization (7th ed), Mason, $\mathrm{OH}$ : Thomson South-Western.

[3] Koller, T., Goedhart, M., Wessels, D., 2005. Valuation: Measuring and Managing the Value of Companies (4th ed), Hokoben, NJ: John Wiley \& Sons.

[4] Wheelen, T. L., \& Hunger, J. D., 2012, Strategic Management and Business Policy (13th ed), New Jersey: Pearson Prentice Hall.

[5] Kotler, P., \& Amstrong, G., 2012, Principles of Marketing, New Jersey: Pearson Prentice Hall.

[6] Porter, M.E., 1985. Competitive Advantage: Creating and Sustaining Superior Performance. New York: N.Y. Free Press.

[7] Ruud, J. A., Näs, J., Tortorici, V., 2007, McKinsey on Finance (Perspectives on Corporate Finance and Strategy), McKinsey \& Company, 24: 1-5.

[8] Mariama, R., \& Wandebori, H., 2016, Business Strategy Evaluation In Low Crude Oil Price Environment, International Conference on Ethics of Business, Economics, and Social Science, ISSN: 2528617X: 13-26.

[9] Andika, C. C., \& Wandebori, H., 2019, Posisi Strategis Jasa Pelayanan Paket Pos Indonesia Di Era E-Commerce, Manajemen Strategi Dalam Perspektif Indonesia, 281-298.

[10] Puspitasari, A., Jamal, M., \& Hasanah, N., 2019, Inovasi Layanan PT Pos Indonesia Dalam Peningkatan Pelayanan Sebagai Upaya Menjaga Eksistensi Di Era Persaingan Global, eJournal Ilmu Pemerintahan, Vol 7 (2): 647-660.

[11] Rukmana, E., 2018, Analisis Dan Usulan Strategi Alternatif Divisi Pengembangan Bisnis Surat PT Pos Indonesia (Persero) Menggunakan Quantitative Strategic Planning Method, Thesis, Sekolah Pascasarjana, Magister Management, Universitas Katolik Parahyangan, Bandung.

[12] Sukwandi, Y. G., 2018, Evaluation New E-Business Process performance Of PT Pos Indonesia Using E-Service Flexibility and CAC Framework, Final Project, SBM, MBA, Institut Teknologi Bandung, Bandung.

[13] Pribudi, G., 2018, A Preliminary Study to Define PT Pos Indonesia Turnaround Strategy, Final Project, SBM, MBA, Institut Teknologi Bandung, Bandung.

[14] Ekaputra, H., 2019, Proposed Marketing Strategy to Return Brand Images Of PT Pos Indonesia, Final Project, SBM, MBA, Institut Teknologi Bandung, Bandung.

[15] Jauhari, A. T., 2019, the Readiness Of Implementing Human Resources Digitalization System Using Human Capital Management Maturity And Organizational Agility (Case Study At Pos Indonesia), Final Project, SBM, MBA, Institut Teknologi Bandung, Bandung.

[16] Kementrian Koordinator Bidang Perekonomian Republik Indonesia, 2019, Outlook Perekonomian Indonesia 2019 (Meningkatkan Daya Saing Untuk Mendukung Ekspor), May, 1: 16-54.

[17] Universal Postal Union, 2019, Postal Development Report 2019 (Perspectives On The Performance Of Postal Operators Worldwide), October, 9-16.

[18] Annual Report PT Pos Indonesia 2018, from https://www.posindonesia.co.id/id/content/41

[19] Indonesia's Economic Data: GDP, from https:// www.bps.go.id.

[20] Five Highest Ranking of Courier Service Industry on 2019, from https://www.topbrand-award.com/top-brand-index.

[21] Road Map e-Commerce Indonesia of 2017 - 2019, from https:// www.indonesiabaik.id.

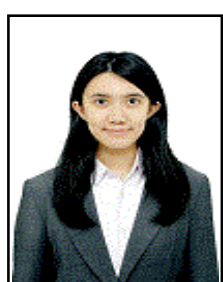

Ignasia Tiffani earned her undergraduate degree (Majoring in Accounting) from Parahyangan Catholic University, Indonesia in 2017. Currently, she is pursuing her master's degree in Master of Business Administration, Bandung Institute of Technology.

She worked as an auditor at an external audit company in 2017. And she worked as an accountant at a jewelry company in 2018

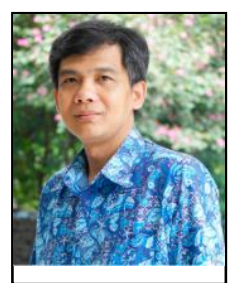

Harimukti Wandebori earned his undergraduate degree (Majoring in Electrical Engineering) from Bandung Institute of Technology, Indonesia in 1990 He continued his study at Maastricht School of Management, Netherlands in 2001 to get MBA degree and get his doctorate degree from University of Twente, Netherlands in 2016.

Harimukti Wandebori is currently a lecturer at the School of Business and Management Institute of Technology Bandung (SBM ITB) and faculty member at Business Strategy and Marketing research interest group. He was one of the best Civil Servant Candidates when he entered as a lecturer at SBM ITB. He has made many articles in national and international journals with the theme of strategy management, strategic alliances, and marketing management 